\title{
PENGARUH CORPORATE GOVERNANCE TERHADAP TAX AVOIDANCE DENGAN MEDIASI LIKUIDITAS PADA PERUSAHAAN BUMN YANG TERDAPAT DI BEI TAHUN 2017-2019
}

\author{
Vio Lolyta Manurung ${ }^{1}$, Francis Hutabarat ${ }^{2}$ \\ ${ }^{1,2}$ Akuntansi, Ekonomi, Universitas Advent Indonesia, Jl. Kolonel Masturi No.288 ,Bandung, 40559, Indonesia \\ ${ }^{2}$ E-mail: fmhutabarat@unai.edu
}

\begin{abstract}
The aims of this study is to test the effect of corporate governance on tax avoidance by using liquidity as a mediation in state-owned companies (BUMN) that have been listed on the Indonesia Stock Exchange (BEI) for the 2017-2019 period. This study uses descriptive analysis theory and processing is carried out in SPSS software. There are 20 state-owned companies (BUMN) listed on the Indonesia Stock Exchange (BEI) for the 2017-2019 period which were used as samples in this study. This study uses tax avoidance which functions as the dependent variable and uses corporate governance which functions as an independent variable and is assisted by using liquidity as a mediating variable. In addition, descriptive statistics, $F$ test, and t test were also used in this study as statistical analysis. The results of the analysis in this study show that corporate governance has a significant effect on tax avoidance, while liquidity does not have a significant effect on tax avoidance with liquidity as the mediating variable.
\end{abstract}

Keywords: corporate governance; tax avoidance; liquidity

\section{PENDAHULUAN}

Pada zaman dulu rakyat harus memberikan kewajiban kepada negara yang berbentuk tenaga atau bisa seperti kekuatan fisik, keterampilan serta keahlian, Selain daripada itu ada harta benda dan hasil bumi. Namun, pada zaman sekarang umumnya sudah berupa uang. Pajak merupakan salah satu bentuk kekayaan yang dimiliki oleh negara dan kewajiban setiap badan maupun individu sesuai dengan Undang-Undang Perpajakan (Markus dan Yujana, 2002:1). Melalui sektor pajak negara mendapatkan penghasilan besar (Mulyani et al., 2018). Adanya resolusi yang dilakukan oleh pemerintah dalam hal pembangunan dan pengembangan negara juga mengacu kepada kehidupan sosial ekonomi masyarakat itu sendiri. Dikalangan masyarakat yang mampu atau tidak mampu, pajak adalah beban karena mampu untuk mendapatkan sebagian keuntungan dari penghasilan saat melakukan transaksi pembayaran pajak. Adanya resolusi yang dilakukan oleh pemerintah dalam hal pembangunan dan pengembangan negara juga mengacu kepada kehidupan sosial ekonomi masyarakat itu sendiri.

Selain dari masyarakat, penghindaran pajak juga dilakukan oleh perusahaan dikarenakan cara dan proses tersebut bersifat secara resmi bagi seseorang yang wajib pajak dan tidak akan adanya terjadi bentrok pada keputusan pajak. Tata cara serta pola didukung dengan menggunakan suatu kelemahan yang terkandung dalam peraturan perpajakan dan peraturan perundang-undangan (Saputra dan Asyik, 2017). Dalam menjalankan bisnis tentunya perusahaan perlu untuk memikirkan tentang suatu risiko yang akan terjadi saat menjalankan bisnis, oleh sebab itu pada era globalisasi saat ini suatu perusahaan harus mampu untuk menerapkan praktik tata kelola perusahaan yang bertujuan dalam meminimalisasi risiko bisnis. Menurut kajian tentang tata kelola perusahaan dari penjelasan temuan penelitian mengatakan bahwa kajian dari suatu perusahaan sebagai proses dan tujuan 
akhir dalam mencapai serangkaian hubungan antara manajemen dengan perusahaan untuk menjangkau maksud dan tujuan dari kemampuan yang diperoleh (Winata, 2014).

Tata kelola perusahaan (corporate governance) mampu untuk mengendalikan semua pemegang saham dalam menghasilkan nilai tambah (value added) bagi perusahaan. Perbedaan bagi perusahaan dan tata kelola perusahaan yaitu menjelaskan bahwa sebuah perusahaan merupakan salah satu bagian yang harus melakukan wajib pajak, sedangkan sebuah tata kelola perusahaan merupakan suatu relasi yang terjadi pada setiap perusahaan yang memiliki sebuah partisipan untuk dapat menentukan suatu arah kinerja dalam perusahaan. Kewajiban yang sesuai dengan definisi dari pajak adalah suatu tata kelola perusahaan yang memiliki tingkah laku baik pajak, sedangkan perusahaan beranggapan bahwa pajak adalah beban, oleh sebab itu perusahaan berusaha untuk melaksanakan perencanaan pajak yang memiliki tujuan penghematan dalam membayar pajak sehingga perusahaan tidak akan melanggar peraturan perpajakan yang berlaku. Jika suatu proses kegiatan yang sudah tersusun rapi oleh perusahaan maka akan memenuhi kepatuhan dari kewajiban perpajakannya (Winata,2014).

Menurut (Winata, 2014), tata kelola perusahaan dalam suatu perusahaan akan menimbulkan pengaruh yang signifikan pada hasil penghindaran pajak. Fenomena yang terjadi perbedaan pada temuan penelitian dimana satu penelitian yang dilakukan oleh Sarasati dan Asyik, 2018 yang menyatakan bahwa penerapan tata kelola perusahaan pada suatu perusahaan sama sekali tidak menimbulkan pengaruh yang signifikan pada penghindaran pajak.

Terdapat hal-hal lain yang akan memengaruhi penghindaran pajak. Menurut Adisamartha dan Noviari (2015), likuiditas berpengaruh secara positif terhadap penghindaran pajak, dapat terlihat dari perusahaan yang memiliki agresivitas pajak dan memiliki tingkat likuidasi tinggi sehingga adanya hubungan dengan profitabilitas tinggi maka hasil tersebut akan terpengaruh oleh likuiditas. Likuiditas merupakan tolak ukur pada perusahaan dalam memenuhi kewajiban jangka pendek yang dicerminkan dari aktiva lancarnya relatif pada utang lancarnya. Likuiditas juga dapat menghitung dampak dari ketidakmampuan perusahaan dalam memenuhi kewajiban jangka pendek. Penelitian ini menggunakan likuiditas current ratio (Alam dan Fidiana, 2019). Hal ini juga ikut didukung oleh fenomena lain yang terjadi terkait likuiditas yang bertentangan pada penelitian yang telah dilakukan oleh (Suyanto dan Supramono, 2018) bahkan likuiditas dan penghindaran pajak tidak memiliki pengaruh yang signifikan.

\section{TINJAUAN PUSTAKA}

\subsection{Teori keagenan}

Teori yang menyatakan hubungan pemegang sama sebagai prinsipal dan manajemen sebagai agen merupakan konsep dari teori keagenan. Pemegang saham akan memberikan kontrak manajemen untuk berkerja bagi kepentingan pemegang saham. Temuan penelitian mengatakan setiap manajer akan diberikan kekuasaan untuk membuat keputusan. Namun hal inilah yang nantinya akan menghasilkan konflik kepentingan yang kita ketahui sebagai teori keagenan. Teori keagenan menggambarkan kenyataan yang ada, sehingga dapat dipandang lebih luas serta mendasari pemikiran tentang tata kelola perusahaan, yang dimana untuk mengelola perusahaan, harus terdapat pengawasan dan pengendalian untuk memastikan perusahaan dikelola sesuai dengan peraturan dan ketentuan yang ada. Akibat adanya perbedaan kepentingan antara pemegang sama dan manajer inilah yang disebut dengan teori keagenan. Para manajer demi melaksanakan kepentingannya tidak jarang akan menyembunyikan informasi yang dibutuhkan oleh pemegang saham. Hal ini akan memicu adanya pemasalahan yang akan mengakibatkan pada munculnya biaya (Mulyani et al., 2018) 
Konsep yang menggambarkan kontraktual dan managemen (agent) pemilik perusahaan dan hubungan antara keduanya disebut dengan teori keagenan. Adapun agen merupakan pihak yang memiliki kewajiban untuk sebaik-baiknya mengurus perusahaan. Namun sejalan dengan kewajiban dan tanggung jawab yang berat yang dimiliki oleh agen, harus didukung dengan kompensasi yang sesuai. Hal ini lah yang sering menimbulkan terjadinya konflik diantara agen dan prinsip dasar. Dengan terjadinya konflik antara principle dan agen disebabkan oleh karena adanya asymmetric information, yang memimbulkan adanya ketidakseimbangan informasi diantara kedua pihak. Penilaian diri (Self assessment) yang diberlakukan di Indonesia menjadi peluang bagi agen, sehingga dapat menghitung sendiri pajak mereka. Pihak perusahaan memiliki perbedaan kepentingan dengan pemungut pajak, dimana para pemungut pajak menginginkan adanya pemasukan besar dari pajak, sedangkan pihak agen menginginkan perolehan laba yang besar dan beban pajak yang kecil. Oleh sebab perbedaan kepentingan inilah, diantara fiskus yang berfungsi sebagai pemotong pajak dan pihak manajemen yang berfungsi sebagai pembayar pajak sering terjadi pertentangan (Alam dan Fidiana, 2019).

\subsection{Pajak (Tax)}

Menurut Undang-Undang Nomor 16 Tahun 2009 Pasal 1 Ayat (1) tentang Ketentuan Umum Perpajakan menjelaskan bahwa: Pajak adalah kontribusi wajib kepada negara yang terutang oleh orang pribadi atau badan yang bersifat memaksa berdasarkan UndangUndang, dengan tidak mendapatkan imbalan secara langsung dan digunakan untuk keperluan negara bagi sebesar-besarnya kemakmuran rakyat (Sari dan Devi, 2018).

Menurut UU KUP Nomor 28 tahun 2007, pasal 1, ayat 1, Pajak adalah kontribusi wajib kepada negara yang terutang oleh orang pribadi atau badan yang bersifat memaksa berdasarkan undang-undang, dengan tidak mendapatkan imbalan secara langsung dan digunakan untuk keperluan negara bagi sebesar-besarnya kemakmuran masyarakat (Wulandari, 2019).

Komponen yang mendukung dalam pencapaian negara disebut dengan pajak. Adapun yang lain tentang penempatan pajak sebagai salah satu diantara kewajiban bernegara bagi masyarakat dan didampingi pemerintah untuk memaksimalkan penerimaan sektor perpajakan dengan cara upaya yang intensifikasi dan eksentifikasi dalam penerimaan jumlah pajak. Pandangan terhadap ketaatan wajib pajak yang diharuskan dalam pembayaran pajak sesuai dengan kondisi yang sebenarnya (Tandean, 2018).

\subsection{Penghindaran pajak (tax avoidance)}

Hampir diseluruh negara yang menjadi sorotan adalah penghindaran pajak terutama dalam perkembangan bisnis pada era sekarang ini sehingga memiliki hubungan yang istimewa antar lintas bisnis negara. Serta penghindaran pajak merupakan suatu hambatan yang sering terjadi saat diadakannya pemungutan pajak, adapun cara untuk menghindari ketetapan pasal-pasal yang sudah dibuat oleh pemerintah itu tetap sama saja ada akibatnya yakni berkurangnya penerimaan kas negara. Kegiatan yang bersifat legal selalu berhubungan dengan penghindaran pajak (tax avoidance) misalnya pengurangan beban pajak tanpa adanya perlawanan dari ketentuan perpajakan. Dalam upaya penghindaran pajak didalam perusahaan yaitu meminimalkan beban pajak yang ada, namun tidak melanggar perarturan yang ada yaitu cara yang cukup elegan (Wulandari, 2019). Adanya cara perusahaan untuk memperkecil laba dan jumlah merupakan suatu usaha dari perusahaan tersebut. Ini dikarenakan suatu hambatan dengan perlawanan untuk penghindaran pajak agar tidak terjadi pengurangan kas negara yang sudah ditetapkan dengan peraturan perundang-undangan perpajakan. Disisi lain tax avoidance (penghindaran pajak) menguntungkan bagi perusahaan, tetapi dapat menimbulkan kerugian bagi negara serta membuat penghasilan negara menurun (Rahmawati et al., 2016).

Dengan melalui kebijakan seorang pemimpin perusahaan untuk menentukan karakteristik perusahaan menjadi penentu dalam pengambilan tindakan dari penghindaran 
pajak. Bahkan karakteristik tersebut menjadi entitas usaha. Tingkat likuiditas dapat dipengaruhi tingkat penghindaran pajak (Oktrayanti dan Utomo, 2017). Meminimalisir beban pajak dapat dilakukan dengan cara memulai dari peraturan perpajakan hingga pelanggaran perpajakan yang berlaku. Upaya untuk penghematan pajak secara eufimisme dapat dikatakan sebagai perencanaan pajak (tax planning) (Annisa dan Kurniasih, 2012)

Indikator rasio tingkat pembayaran pajak yang efektif Effective Tax Rate dalam melakukan pengukuran pada penghindaran pajak. Maka penulis terdahulu dalam penulisan memerlukan Effective Tax Rate menjadi indikator dari tax avoidance. Mengenai Effective Tax Rate tahapan untuk memahami seberapa pentingnya efektif pajak dalam satu perusahaan, menciptakan kesimpulan serta membagikan beban pajak penghasilan terhadap laba sebelum pajak. Effective Tax Rate (ETR) menggunakan metode:

$$
\mathrm{ETR}=\frac{\text { Tax Expense }_{\mathrm{i}, \mathrm{t}}}{\text { Pretax }_{\text {Income }}}
$$

\subsection{Tata kelola perusahaan (corporate governance)}

Di Indonesia, isu tentang tata kelola perusahaan sudah terjadi sejak tahun 1998, hal itu terjadi saat Indonesia mengalami krisis moneter yang berkepanjangan. Sejak saat itu perekonomian di Indonesia sangat sulit untuk kembali normal, penyebab sulitnya perekonomian yang Kembali normal diakibatkan oleh penerapan sistem tata kelola perusahaan yang masih lemah pada perusahaan-perusahaan di Indonesia. Setelah kejadian 1998 itu pemerintah maupun investor mulai memperhatikan sistem tata kelola perusahaan secara signifikan, tata kelola perusaan yaitu sebuah sistem yang mampu menjalin hubungan pada pihak manajemen dengan pemilik saham di suatu perusahaan (Damayanti dan Susanto, 2015). Setiap perusahaan harus mampu untuk menerapkan tata kelola perusahaan dan tidak melakukan penghindaran pajak, sebab dengan diterapkannya tata kelola perusahaan mampu untuk meminimalisir terjadinya tax avoidance. Tata kelola perusahaan adalah salah satu faktor yang sangat penting untuk menentukan penilaian dalam penghematan pajak, artinya suatu perusahaan yang telah melakukan penerapan sistem tata kelola perusahaan secara terstruktur dengan baik maka akan diikuti juga dengan kepatuhan perusahaan dalam memenuhi kewajiban pajaknya. Tugas dalam komisiaris independen dan komite audit berfungsi menjadi proksi pada tata kelola perusahaan (Utari dan Supadmi, 2017). Tata kelola perusahaan memainkan beberapa peran, yaitu terdiri dari: pengawas atas penghindaran pajak, dan penentu keputusan penghindaran pajak. Tata kelola perusahaan juga berlaku sebagai pembentukan tata kelola dari suatu perusahaan untuk menentukan sebuah arah perusahaan agar hasil dari tata kelola tersebut sesuai dengan karakter dari pimpinan perusahaan, karakter seorang pimpinan adalah mampu dalam mempengaruhi suatu keputusan yangterjadi dalam perusahaan dan juga termasuk dalam penghindaran pajak (Mulyani et al., 2018). Terdapat beberapa mekanisme dalam Tata Kelola Perusahaan, diantaranya:

Struktur Dewan Komisaris. Komisaris independen adalah orang yang terafiliasi dengan para pengendali yang tidak lain adalah pemegang saham dan tidak adanya hubungan afiliasi terhadap direksi dan sebaiknya tidak memiliki jabatan termasuk direktur dalam perusahaan tersebut atau yang bersangkutan dengan Bursa Efek Indonesia (BEI) jumlah komisaris independen terdiri dari 30\% sudah termasuk keseluruhan anggota komisaris, namun untuk menjadi komisaris independent wajib mampu mengerti UU dan juga peraturan yang mengatur pasar modal tersebut dan mendapatkan usulan dari para stakeholders ada saat RUPS diadakan (Annisa dan Kurniasih, 2012).

Orang yang tidak memiliki hubungan terhadap pemegang saham dapat dikatakan sebagai komisaris independen. Selain itu harus tidak adanya kaitan dengan relasi terhadap direksi serta jajaran komisaris, dan sama sekali tidak memiliki jabatan direktur suatu 
perusahaan tersebut. Di dalam BEI memiliki tatanan tentang Suatu perusahaan itu wajib mempunyai dewan komisari Independen yg terdiri dari 30\% Terhitung seluruh anggota dari dewan komisaris yang ada,sehingga pengawasan yang dilakukan dapat semudah mungkin dan sedemikian rupa (Rahmawati et al., 2016). Berdasarkan peraturan yang telah ditetapkan oleh BEI mulai dari total keseluruhan dari dewan komisaris Independen hingga keseluruhan saham dari seluruh anggota komisaris,namun Untuk menjadi seorang Komisaris independen diharapkan mampu UU dan peraturan yang mengatur tentang pasar modal yang berlaku dan telah memiliki rekomendasi dari pemegang saham yang bukan pemegang saham pengendali dalam rapat umum pemegang saham (Subagiastara, 2016:14).

Keterangan:

$$
\text { PDKI }=\frac{\text { Jumlah Dewan Komisaris Independen }}{\text { Jumlah Dewan Komisaris }} \times 100 \%
$$

PDKI $=$ Proporsi Dewan Komisaris Independen

Komite audit dengan penghindaran pajak. Dewan komisaris perusahaan akan membentuk suatu komite yang bernama komite audit, anggota dari komite audit hanya dapat diangkat dan pemberhentian anggota dilakukan oleh dewan komisaris untuk melanjutkan tugas juga dalam mengakomodasi untuk melayani pengawasan dan penelitian sangat diperlukan dalam melaksanakan fungsi kepengurusan untuk manajeman perusahaan. Sedangkan, komite audit adalah elemen yang sangat dipentingkan didalam suatu perusahaan jika sudah tercatat pada Bursa Efek Indonesia maka dari itu BEI mengusulkan untuk menyusun kepengurusan komite audit dan harus diketahui oleh komisaris independen. Diharapkan setiap perusahaan yang sudah memiliki komite audit mampu untuk meningkatkan kualitas dari pengawasan internal, sehingga mampu untuk memberikan pengawasan perlindungan terhadap pemegang saham serta lainnya. Komite audit bertugas untuk meringankan pengawasan yang dilakukan dewan komisaris pada prestasi yang dicapai oleh suatu perusahaan, selain itu jajaran dari dewan komisaris juga memiliki fungsi untuk menjembatani perusahaan dengan bentuk eksternal auditor. Komite audit juga sangat berkaitan baik terhadap kajian dari risiko melalui perusahaan serta kepatuhan pada aturan. Komite audit mampu mengurangi pengukuran Tindakan kecurangan serta tindakan yang diidentifikasi melanggar hukum dengan cara pengungkapan akuntansi. Kebijakan dari penghindaran pajak yang sering disebut penghindaran pajak tentu akan mudah atau menurun apabila cukup banyak anggota dari komite audit (Winata, 2014). Temuan penelitian yang dilakukan oleh Wardhani (2006), berpendapat mengenai suatu kasus yang terjadi pada implementasi tata kelola perusahaan ini dengan direktur utama yang memiliki wewenang luas apabila dibandingkan dengan dewan komisaris. Sedangkan jika diperhatikan bahwa dewan komisaris sangan memiliki fungsi yang sangat besar, karena berfungsi untuk memeriksa kemampuan dari dewan komisaris yang dipimpin oleh CEO pada perusahaan. Maka sebab itu komisaris independen sangat diperlukan untuk kekuatan pengendali. Komisaris independen adalah komite perusahaan yang memiliki anggota dewan komisaris independen yang bukan bersumber melalui perusahaan dan memiliki fungsi untuk mengevaluasi cara kerja suatu perusahaan secara luar serta menyeluruh (Mulyani et al., 2018).

Komite audit. Pembentukan tujuan dari adanya komite audit ini untuk meminimalisir atau meringankan tugas komisaris audit yang bertugas sebagai pengawas pengendalian internal serta bertugas sebagai auditor luar dan dalam. Akses untuk dapat menghubungkan dengan pihak manajerial serta pihak internal serta semua informasi tentang entitas perusahaan hanya dapat dimiliki oleh komite audit. Oleh karena itu komite audit memiliki fungsi untuk melakukan bantuan pada pihak manajerial dalam intermediaries atau yang menjembatani pihak manajerial perusahaan pada auditor eksternal pada suatu perusahaan (Rahmawati et al., 
2016). Sebagai alat ukur penelitian menggunakan jumlah komite audit dalam sebuah perusahaan (Subagiastara, 2016:14).

Likuiditas. Kemampuan perusahan dalam memenuhi kewajiban jangka pendek seperti tagihan listrik, telepon, air, gaji, dan yang lainnya dapat diukur menggunakan likuiditas perusahaan. Penelitian terdahulu menyebutkan jika likuiditas suatu perusahaan rendah maka akan memiliki kemungkinan untuk tidak memenuhi kewajiban jangka pendeknya, tidak mematuhi peraturan perpajakan, serta melakukan pengindaran pajak (Sarasati dan Asyik, 2018). Likuiditas adalah tolak ukur perusahaan dalam memenuhi kewajiban jangka pendek yang dicerminkan dari aktiva lancarnya relatif pada utang lancarnya. Likuiditas juga dapat menghitung dampak dari ketidakmampuan suatu perusahaan dalam melakukan kepatuhannya pada kewajiban jangka pendek. Penelitian ini menggunakan likuiditas current ratio (CR) (Alam dan Fidiana, 2019). Temuan penelitian terdahulu menggunakan current ratio, quick ratio, dan cash rasio sebagai alat unntuk melakukan pengukuran likuiditas. Menurut Wallace (1994) menjelaskan bahwa perusahaan yang sehat dapat di ukur dengan current ratio, oleh karena itu juga penelitian ingin menggunakan current ratio sebagai alat pengukuran yang sehat atau tidaknya suatu perusahaan dalam penelitian ini (Budianti dan Curry, 2018). Rumus yang digunakan dalam current ratio yaitu:

$$
\mathrm{CR}=\frac{\text { Aktiva Lancar }}{\text { Utang Lancar }}
$$

\subsection{Penelitian terdahulu}

Corporate governance terhadap tax avoidance. Menurut temuan penelitian yang telah dilakukan oleh Sari (2013) menyatakan bahwa tidak ada memiliki pengaruh dari bagian manajemen buat memeriksa laporan keuangan yang berbobot ini merupakan peran dari dewan komisaris yang berhasil. Pengaplikasian dari komisaris independen membantu untuk memantau pengendalian perusahaan yang bagus untuk membentuk laporan keuangan semakin faktual. Laporan keuangan yang baik dilatarbelakangi oleh adanya anggota komite audit yang bekerja sesuai fungsinya secara benar dan sesuai regulasi yang berlaku, hal itu juga mampu mengendalikan serta mendukung perusahaan dalam good corporate governance (Annisa dan Kurniasih, 2012). Pada penelitiannya Winata (2014) bahwa corporate governance mampu menimbulkan efek pengaruh positif pada tax avoidance. Rahmawati et al. (2016) mengemukakan hal yang sama dalam penelitiannya. Namun hal tersebut berbeda dengan suatu penelitian yang telah dilakukan oleh Sarasati dan Asyik (2018) bahwa corporate governance tidak mampu untuk menimbulkan suatu pengaruh yang signifikan terhadap tax avoidance.

H1: Corporate governance memiliki pengaruh yang signifikan terhadap tax avoidance

Likuiditas terhadap tax avoidance. Teori keagenan menjelaskan bahwa pengawasan serta kontroling yang baik dapat dilihat dari jumlah komisaris independen, jika semakin banyak maka semakin baik juga tindakan manajernya. Dalam suatu premis bahwa teori keagenan yaitu bagian komisaris independen sangat dibutuhkan oleh dewan komisari dalam melakukkan pengawasan serta pengontrolan untuk tindakan manajer, sehubungan dengan perilaku oportunistiknya. Berdasarkan hasil temuan penelitian telah menjelaskan bahwa dengan adanya dewan komisaris independen, corporate governance sangat berpengaruh secara signifikan pada tax avoidance (Mulyani et al., 2018). Berdasarkan temuan penelitian telah menjelaskan bahwa suatu perusahaan yang tidak mentaati tentang suatu aturan perpajakan yang berlaku maka akan lebih cenderung untuk penghidaran pajak adalah suatu perusahaan yang keadaannya sedang dalam permasalahan likuiditas. Sedangkan, perusahaan yang memiliki likuiditas tinggi adalah perusahaan yang selalu memenuhi hutang lancarnya 
dan mencerminkan bahwa perusahaan tersebut dalam keadaan sehat dari segi keuangan serta sedang tidak memiliki masalah dalam arus kas yang membuat suatu perusahaan tersebut mampu untuk memenuhi biaya pajak (Alam dan Fidiana, 2019). Namun temuan penelitian lainnya mengatakan hal yang berbeda bahwa current ratio tidak menimbulkan pengaruh yang signifikan pada penghindaran pajak (Budianti dan Curry, 2018).

H2: Likuiditas menimbulkan pengaruh yang signifikan terhadap tax avoidance

\section{METODE PENELITIAN}

\subsection{Sumber data}

Jenis data yang digunakan dalam penelitian ini adalah data sekunder, keseluruhan data pada penelitian didapat pada Bursa Efek Indonesia yang merupakan pembekalan bagian dari laporan keuangan. Pada periode 2017-2019 yang sudah diolah pada laporan keuangan Badan Usaha Milik Negara (BUMN).

\subsection{Populasi dan sampel}

Penelitian ini memanfaatkan perusahaan-perusahaan yang sudah terverifikasi pada Bursa Efek Indonesia (BEI) sebagai populasi, secara tidak keseluruhan mengkaji populasi melainkan hanya sebagian saja dari perusahaan BUMN. Sejumlah 20 perusahaan BUMN pada tahun 2017-2019 yang terdaftara pada BEI dan dijadikan sebagai populasi pada penelitian, sehingga ada 60 data untuk diolah menjadi sebuah sampel.

\subsection{Variabel penelitian}

Melalui penelitian model yang memiliki dua variabel bebas (X1) CG yang digunakan sebagai alat ukur penelitian menggunakan jumlah komite audit dalam sebuah perusahaan (X2) likuiditas yg diukur menggunakan current ratio dan variabel terikat (Y) tax avoidance dengan menggunakan alat ukut ETR.

\subsection{Analisis data}

Seperti teknik analisis data dari uji koefisien determinasi, significant test, dan regresi berganda. Data yang sudah terakumulasi akan dioperasikan memakai perangkat lunak SPSS dan menjadi peranan sebagai pengolahan data.

\section{HASIL PENELITIAN DAN PEMBAHASAN}

\subsection{Hasil penelitian}

Hasil uji kelayakan model (Uji F). Tabel 1 menunjukkan bahwa corporate governance terhadap tax avoidance tidak menimbulkan pengaruh yang signifikan pada model 1. Hal ini dapat dilihat dari nilai F-test 0.382 dan nilai significan 0.540 pada $\alpha=0.10$ atau $10 \%$. Sedangkan pada model 2 , didapati bahwa dengan adanya mediasi likuiditas maka didapati pengaruh corporate governance, likuiditas pada tax avoidance memiliki tingkat signifikannya yaitu 0.086 pada $\alpha=0.10$ atau $10 \%$ dengan F-test 2.626.

Tabel 1. Hasil uji kelayakan model ANOVA

\begin{tabular}{cccc}
\hline & Model & F & Sig. \\
\hline 1 & Regression & 0.382 & 0.540 \\
2 & Regression & 2.626 & 0.086 \\
\hline
\end{tabular}

Hasil uji hipotesis (Uji t). Tabel 2 untuk hasil uji signifikan menunjukkan bahwa diantara variabel independen maka terlihat bahwa pada model 1 tidak ada pengaruh signifikan pada variabel corporate governance terhadap tax avoidance dengan nilai signifikan 0.540 pada level signifikan 5\%. Sedangkan pada model 2, didapati dengan adanya mediasi likuiditas, didapati dalam corporate governance dan tax avoidance tetap saling menimbulkan pengaruh yang tidak signifikan yaitu 0.152 pada level signifikan $5 \%$. Dan terkait likuiditas dan tax avoidance didapati adanya pengaruh yang signifikan dengan tingkat 
signifikan 0.034 pada level signifikan 5\%. Dengan demikian keberadaan likuiditas sepenuhnya memediasi pengaruh corporate governance dan tax avoidance. Adapun model regresi yang didapat adalah:

$\mathrm{TAX}_{1}=0.144+.200 \mathrm{CG}_{1}$

$\mathrm{TAX}_{2}=-0.088+0.490 \mathrm{CG}_{2}+0.001 \mathrm{CR}_{2}$

Tabel 2. Hasil analisis regresi

\begin{tabular}{|c|c|c|c|c|c|c|}
\hline \multirow{2}{*}{\multicolumn{2}{|c|}{ Model }} & \multicolumn{2}{|c|}{ Unstandardized Coefficients } & \multirow{2}{*}{$\begin{array}{c}\text { Standardized Coefficients } \\
\text { Beta }\end{array}$} & \multirow{2}{*}{$\mathbf{t}$} & \multirow{2}{*}{ Sig. } \\
\hline & & B & Std. Error & & & \\
\hline \multirow[t]{2}{*}{1} & Constant & 0.144 & 0.123 & & 1.170 & 0.249 \\
\hline & $\mathrm{CG}$ & 0.200 & 0.323 & 0.100 & 0.618 & 0.540 \\
\hline \multirow[t]{3}{*}{2} & Constant & -0.088 & 0.157 & & -0.560 & 0.579 \\
\hline & $\mathrm{CG}$ & 0.490 & 0.335 & 0.245 & 1.464 & 0.152 \\
\hline & CR & 0.001 & 0.000 & 0.368 & 2.198 & 0.034 \\
\hline
\end{tabular}

Dependent Variable: ETR

Hasil uji korelasi dan determinasi. Tabel 3 menunjukkan bahwa pada model 1 nilai $R$-Square adalah sebesar 0.010 yang berarti kontribusi corporate governance terhadap perubahan pada tax avoidance adalah sebesar $1 \%$. Terkait model 2, didapati bahwa dengan mediasi likuiditas maka didapati kontribusi corporate governance dan likuiditas terhadap perubahan pada tax avoidance menjadi sebesar $12.4 \%$ dan didapati perubahan dalam nilai $R$ Square change sebesar 0.114 atau $11.4 \%$.

Tabel 3. Hasil uji korelasi dan determinasi

\begin{tabular}{ccccc}
\hline Model & $\mathbf{R}$ & $\mathbf{R ~ S q}$ & $\mathbf{R ~ S q}$ Chg & Std. Error of the Estimate \\
\hline 1 & 0.100 & 0.010 & 0.010 & 0.20727 \\
2 & 0.353 & 0.124 & 0.114 & 0.19755 \\
\hline
\end{tabular}

\subsection{Pembahasan}

Corporate governance dan tax avoidance. Penelitian ini menemukan bahwa tata kelola perusahaan (corporate governance) tidak berpengaruh signifikan terhadap penghindaran pajak (tax avoidance). Hasil temuan ini sesuai dengan hasil temuan Sarasati dan Asyik (2018) yang mengatakan corporate governance dan tax avoidance tidak ada pengaruh yang signifikan dan didukung juga oleh Saputra dan Asyik (2017) yang mendukung pernyataan ini. Hasil temuan ini juga mengindikasikan bahwa pelaksanaan tata kelola perusahaan dengan meningkatkan jumlah komisaris independen cenderung meningkatkan juga tingkat pembayaran pajak perusahaan. Seperti yang dikatakan Winata (2014) bahwa corporate governance mampu menimbulkan pengaruh yang positif pada tax avoidance (Rahmawati et al., 2016).

Likuiditas dan tax avoidance. Penelitian ini menemukan bahwa likuiditas berpengaruh signifikan terhadap penghindaran pajak (tax avoidance). Hasil temuan ini sesuai dengan hasil temuan Budianti dan Curry (2018) yang juga mengatakan hal yang sama pada penelitiannya. Hasil temuan ini juga mengindikasikan bahwa dengan meningkatnya likuiditas perusahaan atau kemampuan perusahaan membayar kewajiban jangka pendeknya maka cenderung untuk dapat pula meningkatkan tingkat pembayaran pajak perusahaan. 


\section{KESIMPULAN DAN SARAN}

\subsection{Kesimpulan}

Setelah penelitian ini dapat diselesaikan maka dilakukan pembahasan untuk menyimpulkan bahwa tidak adanya pengaruh yang signifikan dalam corporate governance pada tax avoidance atau H1 ditolak. Namun, pengaruh yang signifikan dapat ditemukan pada likuiditas terhadap tax avoidance atau H2 diterima. Sehingga, dengan menggunakan likuiditas sebagai variabel mediasi maka corporate governance menimbulkan pengaruh yang signifikan pada tax avoidance.

\subsection{Saran}

Dengan dilakukannya sebuah penelitian ini maka dapat disimpulkan suatu saran bagi pihak perusahaan agar lebih waspada terhadap pengambilan keputusan yang terkait dengan manajemen pajak supaya bisa terluput dari sanksi dan untuk melangsungkan penghindaran pajak yang legal ataupun ilegal.

\section{DAFTAR PUSTAKA}

Adisamartha, I. B. P. F. \& Noviari, N. (2015). Pengaruh likuiditas, leverage, intensitas persediaan dan intensitas aset tetap pada tingkat agresivitas wajib pajak badan. $E$ Jurnal Akuntansi, 13(3), 973-1000. https://ojs.unud.ac.id/index.php/Akuntansi/article/view/14496

Alam, H. M. \& Fidiana. (2019). Pengaruh manajemen laba, likuiditas, leverage dan corporate governance terhadap penghindaran pajak. Jurnal Ilmu dan Riset Akuntansi, 8(2), 122.http://jurnalmahasiswa.stiesia.ac.id/index.php/jira/article/view/2181

Annisa, A. N. \& Kurniasih, L. (2012). Pengaruh corporate governance terhadap tax avoidance. Jurnal Akuntansi \& Auditing, 8(2), 1-14. https://ejournal.undip.ac.id/index.php/akuditi/article/view/4352

Budianti, S. \& Curry. K. (2018). Pengaruh profitabilitas, likuiditas, dan capital intensity terhadap penghindaran pajak (tax avoidance). Seminar Nasional Cendikiawan Ke-4, 1-5. https://trijurnal.lemlit.trisakti.ac.id/semnas/article/viewFile/3567/3022

Damayanti, F. \& Susanto. (2015). Pengaruh komite audit, kualitas audit, kepemilikan institusional, risiko perusahaan dan return on assets terhadap tax avoidance. Jurnal Bisnis dan Manajemen, 5(2), 1-20. http://dx.doi.org/10.15408/ess.v5i2.2341

Markus, M., \& Yujana, L. H. (2002). Pajak Penghasilan: Petunjuk umum pemajakan bulanan dan tahunan berdasarkan UU terbaru. Jakarta: PT. Gramedia Pustaka Utama.

Mulyani, S. Wijayanti, A., \& Masitoh, E. (2018). Pengaruh corporate governance terhadap tax avoidance (Perusahaan pertambangan yang terdaftar di BEI). Jurnal Riset Akuntansi dan Bisnis Airlangga, 3(1), 1-19. http://dx.doi.org/10.31093/jraba.v3i1.91

Oktrayanti, Y. T., \& Utomo. (2017). Pengaruh karakteristik perusahaan dan corporate governance terhadap tax avoidance (Studi pada perusahaan manufaktur di BEI). Forum Ilmiah Pendidikan Akuntansi, 5(1), 1-14. http://prosiding.unipma.ac.id/index.php/FIPA/article/viewFile/303

Rahmawati, A., Endang, M. G. Wi. \& Agusti, R. R. (2016). Pengaruh pengungkapan corporate social responsibility dan corporate governance terhadap tax avoidance (Studi pada perusahaan manufaktur yang terdaftar di BEI periode 2012-2014).Jurnal Mahasiswa http://perpajakan.studentjournal.ub.ac.id/index.php/perpajakan/article/view/291 
Saputra, M. D. R., \& Asyik, N. F. (2017). Pengaruh profitabilitas, leverage dan corporate governance terhadap tax avoidance. Jurnal Ilmu dan Riset Akuntansi, 6(8), 1-19. http://jurnalmahasiswa.stiesia.ac.id/index.php/jira/issue/view/75

Sarasati, D. H., \& Asyik, N. F. (2018). Pengaruh good corporate governance, profitabilitas, likuiditas, dan ukuran perusahaan terhadap tax avoidance. Jurnal Ilmu dan Riset Akuntansi, $\quad 7(1)$.

21.http://jurnalmahasiswa.stiesia.ac.id/index.php/jira/article/view/29

Sari, M., \& Devi, P. H. (2018). Pengaruh corporate governance dan profitabilitas terhadap tax avoidance. Jurnal Akuntansi, Prodi. Akuntansi- FEB. UNIPMA, 2(2), 1-9. http://e-journal.unipma.ac.id/index.php/inventory/article/view/3289/1840

Subagiastara, K., Arizona, I. P. E., \& Mahaputra, I. N. K. A. (2016). Pengaruh profitabilitas, kepemilikan keluarga, dan good corporate governance terhadap penghindaran pajak (Studi pada perusahaan manufaktur di Bursa Efek Indonesia). Jurnal Ilmiah Akuntansi. 1(2), 1-27.http://dx.doi.org/10.23887/jia.v1i2

Suyanto, K. D., \& Supramono. (2012). Likuiditas, leverage, komisaris independen, dan manajemen laba terhadap agresivitas pajak perusahaan. Jurnal Keuangan dan Perbankan, $16(2)$, http://jurnal.unmer.ac.id/index.php/jkdp/article/view/1057

Tandean, A. V. (2018). Pengaruh good corporate governance dan ukuran perusahaan terhadap tax avoidance. Proding Seminar Nasional Multi Disiplin Ilmu \& Call For Papers UNISBANK (Sendi_U), 1-10. https://www.unisbank.ac.id/ojs/index.php/sendi_u/article/view/3297/904

Utari, N. K. Y. \& Supadmi, N. L. (2017) Pengaruh corporate governance, profitabilitas dan koneksi politik pada tax avoidance. E-Jurnal Akuntansi Universitas Udayana, 18(3), 2202-2230. https://ojs.unud.ac.id/index.php/Akuntansi/article/view/26206

Wardhani, R. (2007). Mekanisme corporate governance dalam perusahaan yang mengalami permasalahan keuangan. Jurnal Akuntansi dan Keuangan Indonesia, 4(1), 95-114. http://dx.doi.org/10.21002/jaki.2007.05

Winata, F. (2014). Pengaruh corporate governance terhadap tax avoidance pada perusahaan yang terdaftar di Bursa Efek Indonesia Tahun 2013. Tax \& Accounting Review 4(1), 1-11. http://publication.petra.ac.id/index.php/akuntansi-pajak/article/view/3118

Wulandari, Y. (2019). Pengaruh ukuran perusahaan, leverage, dan pertumbuhan penjualan terhadap penghindaran pajak dengan profitabilitas sebagai variabel intervening pada perusahaan manufaktur sektor food \& beverage yang terdaftar di BEI periode 20142018. Jurnal Ekonomi Akuntansi, $4(2), \quad$ 1-16. https://doi.org/10.30996/jea17.v4i02.3303 